The 23rd Lung Cancer Workshop

Gefitinib と Erlotinib

一どう使い分ける?ー

里内美弥子1

\title{
Selective Use of Gefitinib and Erlotinib on Non-small Cell Lung Cancer Patients
}

\author{
Miyako Satouchi 1 \\ ${ }^{1}$ Department of Thoracic Oncology, Hyogo Cancer Center, Japan.
}

ABSTRACT - Gefitinib $\left(\operatorname{Iressa}^{\mathbb{R}}\right)$ and Erlotinib $\left(\right.$ Tarceva $\left.^{\circledR}\right)$ are epidermal growth factor receptor tyrosine kinase inhibitors (EGFR-TKIs) that deliver antitumor effects on non-small cell lung cancer (NSCLC) when used alone. Gefitinib was approved for clinical use in July 2002, resulting in an accumulation of data on its efficacy and safety. Erlotinib was approved in December 2007, effectively allowing the use of two EGFR-TKIs in Japan. Although the approved dose of Gefitinib was roughly one-third of the maximum tolerated dose (MTD), Erlotinib's approved dose is the same as its MTD. A simple comparison of outcomes from domestic Phase II studies on the two drugs apparently does not indicate any significant differences in response or survival. Moreover, there exists no clear evidence on how these two drugs, which have similar mechanisms of action as well as common elements in terms of predictive factors of efficacy, toxicity, and resistance mechanism, can be selectively used, i.e., 'Are there any clinical differences in the populations that respond to the drugs, the efficacy or toxicity?' and 'Can one of the drugs be effective on patients who fail to respond or develop resistance to the other?'. The aim of this paper is to examine the selective use of Gefitinib and Erlotinib through past findings.

(JJLC. 2009;49:950-956)

KEY WORDS - Gefitinib, Erlotinib, Selective use, Patient selection, Epidermal growth factor receptor (EGFR) mutation

Reprints: Miyako Satouchi, Department of Thoracic Oncology, Hyogo Cancer Center, 13-70 Kitaoji-cho, Akashi, Hyogo 673-8558, Japan (e-mail: satouchi@hp.pref.hyogo.jp).

要旨—Gefitinib (イレッサ $\left.{ }^{\circledR}\right)$ と Erlotinib (タルセバ ${ }^{\circledR}$ ) は上皮成長因子受容体チロシンキナーゼ阻害剤（EGFRTKI)であり, 非小細胞肺癌に対し単剤で抗腫瘍効果を有 する薬剤である. Gefitinibは 2002 年 7 月に臨床導入さ れ, 効果や安全性のデータも蓄積されてきている. 一方, Erlotinib が 2007 年 12 月に臨床導入され, 本邦では 2 つの EGFR-TKI が使用可能になった. Gefitinib の承認投 与量が最大耐用量の約 $1 / 3$ 量であるのに対し Erlotinib のそれは最大耐用量と同量で使用されるが, 本邦での第 II 相試験の結果を単純比較すると奏効率や生存率に大差
はなさそうである. 同様の作用機序を有し, 効果予測因 子や毒性, 耐性機序も共通の部分を有するこの 2 剂にお いて, 「奏効する population や効果・毒性に臨床的違い があるのか」，「一方の無効例や耐性化した症例に他方が 有効な場合があるのか」, という「使い分け」を示唆する 明確なエビデンスはない. 本稿では両薬剤についての最 近までの知見を述べて，その使い分けを考えたい. 索引用語——ゲフィチニブ, エルロチニブ, 使い分け, 患者選択, EGFR 遺伝子変異 


\section{はじめに}

Gefitinib (イレッサ $\left.{ }^{\circledR}\right)$ は 2002 年 7 月に世界に先駆け日 本で承認された上皮成長因子受容体チロシンキナーゼ阻 害剂 (epidermal growth factor receptor tyrosine kinase inhibitor ; EGFR-TKI)である. 再発治療でのプラセボと の比較第 III 相試験1で survival benefit が示せなかった もののアジア人の subsetでは有意差をもった survival benefit が示され，実地臨床でしばしば劇的効果を示し， 少なくとも特定の populationの患者さんには優れた臨 床効果をもつことが示されてきており主に非小細胞肺癌 の再発治療で使用されている. Erlotinib (タルセバ®) は プラセボと比較した第 III 相試験 2 で survival benefit を 示した EGFR-TKI であり, 欧米ではこちらが承認され再 発治療に用いられている.

Erlotinib も日本において 2007 年 12 月に承認され, こ れら 2 つ EGFR-TKI が使用できる状況になった. 両剤 ともに EGFR (上皮成長因子受容体) の ATP 結合部位に おいて競合的に作用しリン酸化を阻害するという同様の 作用機序を有し, EGFR の特定の部位に遺伝子変異を有 することや非契煙者, 腺癌という効果予測因子も共通で, 皮疹, 下痢, 肝障害, 間質性肺炎という毒性も共通であ る.1-4 また, 今までに報告されている T790M 遺伝子変 異5 や MET amplification 6 などの耐性機序も共通と考え られている. 両薬剤に毒性や効果の差, 奏効する population の違いなどがあるのかどうかなどを直接比較できる
ような明確な evidence は存在しない.この 2 凨について 「使い分けは可能なのか」, 可能であれば「どう使い分け るのか」は大きな関心事になっている，本稿では両薬剤 についての最近までの知見を述べるとともにそこから導 き出せる両薬剤の違い, 使い分けを述べていきたい.

\section{両薬剈についての概説}

それぞれの薬剤についての profile を Table 1 に示す. 両者キナゾリン骨格を有する低分子の EGFR-TKI であ り, 主に CYP3A4 で代謝されるがその他異なる代謝酵素 も関与している. Erlotinib が最大耐容量 (maximum tolerated dose ; MTD) dose で用いられるのに対し Gefitinib は MTD の約 $1 / 3$ の dose で用いられることより, こ の dose の違いによる効果や毒性の差があると考えられ ている. 最近 38 の小分子 multikinase inhibitor の主要 317 kinase $の$ binding profileを図に表した small molecule-kinase interaction map が示されており 7 (Table 1 内 distinct binding profile で各 kinase に binding があ れば circleで表し affinity の強さが circle の大きさで示 されている) それらを比較すると, やや Erlotinibの方が 活性を示す範囲が広い印象がある。これらのデータから は量的にも守備範囲もやや Erlotinib が優位な印象があ るが, 臨床的に意味のある違いなのかどうかは明らかで はない.

現在までの両薬剤の主要な臨床試験を比較して記載す る. Gefitinib・Erlotinib ともに初回のプラチナ併用療法

Table 1. Profile of Erlotinib and Gefitinib

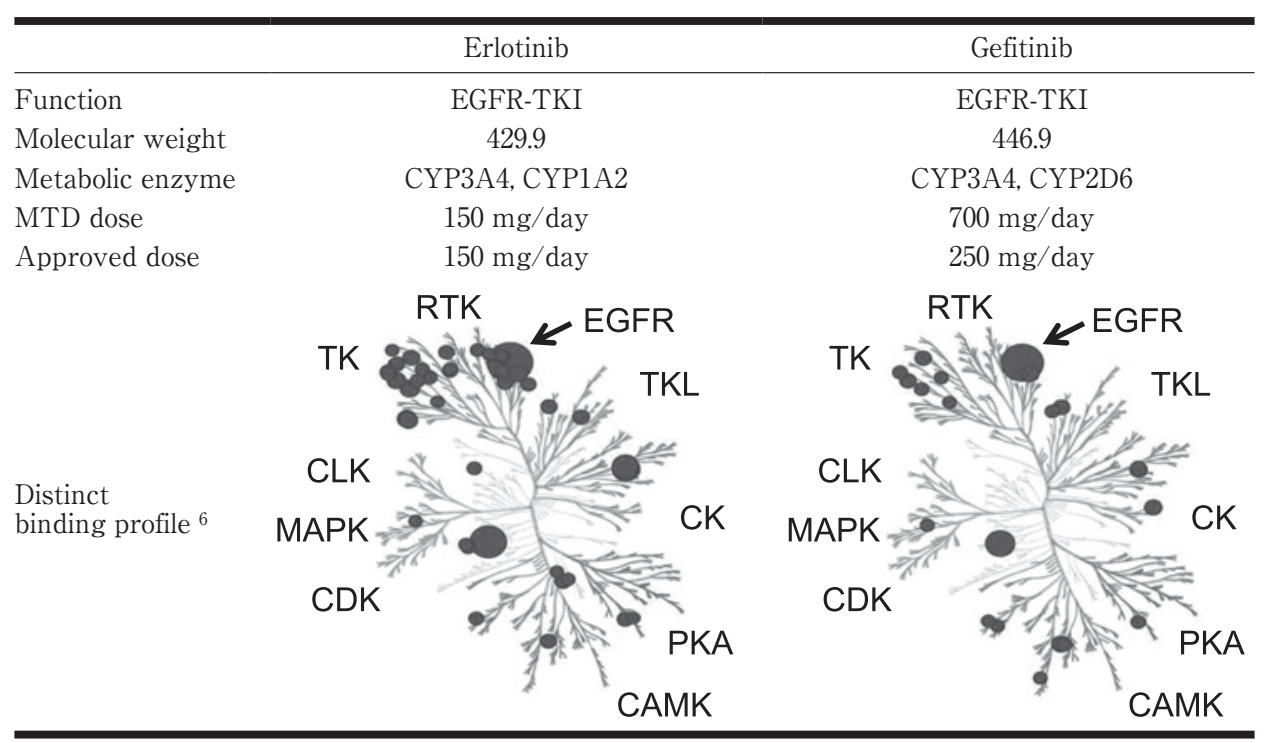

MTD; maximum tolerated dose, RTK; receptor tyrosine kinase, TK; thymidine kinase, CLK; CDClike kinase, MAPK; mitogen activated protein kinase, CDK; cyclin-dependent kinase, CAMK; calcium/calmodulin-dependent protein kinase, PKA; protein kinase A, CK; casein kinase, TKL; tyrosine kinase like group, EGFR; epidermal growth factor receptor. 
Table 2. Japanese Phase II Study Comparing of Erlotinib and Gefitinib

\begin{tabular}{|c|c|c|}
\hline & $\begin{array}{c}\text { Erlotinib } \\
\text { [Integrated } \\
\text { Analysis }{ }^{9} \text { ] } \\
(\mathrm{N}=108)\end{array}$ & $\begin{array}{c}\text { Gefitinib } \\
\text { [IDEAL1 }^{7,8} \text { ] } \\
(\mathrm{N}=51)\end{array}$ \\
\hline \multicolumn{3}{|l|}{ Efficacy } \\
\hline Response rate (\%) & 28.3 & 27.5 \\
\hline Disease control rate (\%) & 49.1 & 70.6 \\
\hline TTP (M) & 2.5 & 3.8 \\
\hline MST (M) & 13.8 & 13.8 \\
\hline \multicolumn{3}{|l|}{ Toxicity (\%) } \\
\hline & & - (IDEAL1) \\
\hline ILD & $4.6 \%(5 / 108)$ & $\begin{array}{l}5.8 \% \text { (PMS) } \\
4.0 \% \text { (CCS) }\end{array}$ \\
\hline Rash & $98.1 \%(106 / 108)$ & $62.7 \%(32 / 51)$ \\
\hline Dry skin & $71.3 \%(77 / 108)$ & $33.3 \%(17 / 51)$ \\
\hline Diarrhea & $72.2 \%(78 / 108)$ & $49.0 \%(25 / 51)$ \\
\hline Pruritus & $69.4 \%(75 / 108)$ & $49.0 \%(25 / 51)$ \\
\hline Anorexia & $38.0 \%(41 / 108)$ & $15.7 \%(8 / 51)$ \\
\hline Fatigue & $37.0 \%(40 / 108)$ & $\begin{array}{r}\text { - (IDEAL1) } \\
0.33 \% \text { (PMS) }\end{array}$ \\
\hline
\end{tabular}

TTP; time-to progression, MST; median survival time, ILD; interstitial lung disease, PMS; post marketing survey, CCS; case control study.

に同時併用することの追加効果をみる第 III 相試験では survival benefit は示されなかった. 再発治療におけるプ ラセボと比較した第 III 相試験においてはGefitinib (ISEL 試験) 1 では survival benefit は示せず, Erlotinib (BR21 試験) 2 では有意差をもって survival benefit が示 された. ISEL では全体としては survivalへの追加効果 は有意差に至らなかったもののアジア人の subset analysis では有意な生存期間の延長が示されている。そ のハザード比は $0.66(\mathrm{p}=0.01)$ であり BR21 のアジア人 subset のハザード比（0.61, $\mathrm{p}=0.06)$ と差がない. アジ ア人では Erlotinib, Gefitinibの効果の差は明らかでは ないようである。この結果をもって欧米では Erlotinib のみが臨床で使用されるようになっており，この 2 用の 使い分けが問題になり検証されるのはアジアのみであ る. 日本における両剤の第 II 相試験での成績を比較する (Table 2) と, 奏効率, 生存期間中央值など効果に関する データはすべてほぼ同等であったが，毒性に関しては MTD dose で行われた Erlotinib で発現率が高かった. 間 質性肺炎の発生率は Gefitinib の第 II 相試験（IDEAL 1) 8.9 の論文では明らかな記載はなかったが, その後の市 販後調查や case control study の結果と比較すると大差 はなさそうである。 また, Erlotinibの試験では（integrated analysis 10) Gefitinib ではほとんど問題にならな かった僚怠感や食欲不振も $1 / 3$ 以上の症例に認めてお り, 毒性は Erlotinib が強そうである。直接比較ではない
が，両者の患者背景は Erlotinib の第 II 相試験において 腺癌が $90 \%$ 以上を占めていたこと（IDEAL1 では 75\%） 以外は大差ないものであり, この結果からは日本人にお いては全体としての効果に著明な差はなさそうである.

\section{Dose difference に関する知見}

上述のとおり, Gefitinib は 1/3 MTD dose, Erlotinib はMTD dose で臨床導入されており, Erlotinib は Gefitinib の 3 倍量ではないかとする論議もある. 実際には in vitro での cell line への薬剤感受性は濃度に対し指数関数 的に増加するので，3 倍量がそのまま 3 倍の効果に結び つくものではない. 両薬剤の血中濃度を参考に EGFRTKI の感受性の異なる各 cell line での IC50を比較す ると効果の期待できる population に少しは差がありそ うであり,11 EGFR 遺伝子変異を有さない患者の中に Gefitinib では奏効せず Erlotinib でのみ効果が得られる 患者群が存在する可能性が示唆されている. しかし, 最 近の EGFR 遺伝子変異の状態が異なる cell line（wildtype, Exon19 deletion, L858R, L848R+T790M）に各 種 EGFR-TKIを作用させた報告12では, Gefitinibの IC50 は Erlotinib より低いことが示されている. また, 分 布容積の違いにより Gefitinib の方が Erlotinibより腫瘍 内濃度が高くなるとも言われており, 臨床検体での報告 によれば腫瘍内濃度は Gefitinib では血中濃度の 40～60 倍, 13 Erlotinib では血中濃度の 0.56 倍14 とされている. 採血のタイミングや投与状況が異なる報告を直接比較し て論ずることはできないが, 血中濃度や MTD dose との 比較がそのまま臨床効果にはつながらないものと考えら れ, やはり臨床に打ける効果の直接比較のみでしか明確 な差は示せないものと考えられる.

IDEAL1 7 においては Gefitinibの $250 \mathrm{mg} /$ body/day と $500 \mathrm{mg} / \mathrm{body} / \mathrm{day}$ を用いて比較を行っている.その 結果毒性は $500 \mathrm{mg} /$ body/dayを用いた群で高頻度で あったが, 奏効率に差はなく以後 Gefitinibは $250 \mathrm{mg} /$ body/day で用いられるようになった（Erlotinibでは投 与量を変えて比較した試験は存在しない). 倍量程度の投 与量の差では効果に大きな差は生じないものと考える一 つの論拠である。一方急性骨髄性白血病や gastrointestinal stromal tumor（GIST）の治療に用いられる EGFR-TKI の Imatinib ではGIST の治療において 400 $\mathrm{mg} / \mathrm{day}$ と $800 \mathrm{mg} / \mathrm{day}$ の投与量の違う 2 群での比較第 III 相試験が行われており, 14 奏効率 $(400 \mathrm{mg} / \mathrm{day}$ 群 : response rate $(\mathrm{RR})=50 \%$, stable disease $(\mathrm{SD})=32 \%$, $800 \mathrm{mg} /$ day 群 : RR $=54 \%, \mathrm{SD}=32 \%$ ）では両者に差は 認めなかったが, 無増悪生存期間（progression free survival；PFS）では有意に $800 \mathrm{mg} /$ day 群で延長していた ことが報告されている（hazard ratio $(\mathrm{HR})=0.82, \mathrm{p}=$ 
0.026). Gefitinib と Erlotinib においても奏効率は変わら なくても, 相対的に量が多い Erlotinib で増悪を遅らせる という仮説も成り立つかもしれないが，その実証には head to head の比較臨床試験が必要となるものと考えら れる.

\section{患者選択に関する知見}

両薬剤ともに奏効に関する予測因子は同様で, アジア 人, 女性, 非契煙者, 腺癌, EGFR 遺伝子変異陽性例での 奏効率が高いことが知られている。 しかし延命に関する 予測因子に関しては両者同様ではない. ISEL, BR21の 両試験での生存期間に関する subset analysisにおいて は非喫煙者では有意差をもって生存期間が延長し （ISEL：HR=0.67，BR21：HR=0.47），契煙者では延長 しない $(\mathrm{ISEL}: \mathrm{HR}=0.93, \mathrm{BR} 21: \mathrm{HR}=0.87)$ など同様の 傾向が示されている．ただし，組織型に関してはISEL 試験では腺癌において有意差に達しないものの生存期間 の延長の傾向が示され, 腺癌とそれ以外の組織型での差 が示唆されたが, BR21では腺癌 $(\mathrm{HR}=0.71)$ だけでなく 扁平上皮癌 $(\mathrm{HR}=0.67)$ の subset においても有意な生存 期間の延長が示されており，より広い患者群で生存期間 の延長が得られる可能性が示唆されている. 2008 年の American Society of Clinical Oncology (ASCO) で西日本 がん研究機構（WJOG）から IIIB・IV 期の非小細胞肺癌 に対して標準的化学療法と標準的化学療法に逐次的に Gefitinibを追加することを比較する第 III 相試験 （WJTOG0203）の結果が報告された. 15 その中で腺癌の subset analysis では逐次的 Gefitinib が有意な生存期間 の延長をもたらしたが, 非腺癌の subset analysis では逆 に逐次的 Gefitinib 追加で生存が短くなる可能性が示唆 された.この結果からは Gefitinibについては非腺癌症例 ではもはや使用すべきではないと考えられる．扁平上皮 癌症例に EGFR-TKI 投与を考慮する際には選択肢は Erlotinib になろうが, 日本人においての第 II 相試験では腺 癌例がほとんどだったことより日本人・非腺癌でのデー 夕が不足していることには注意が必要である. 日本人で は EGFR-TKI で約 5\%に間質性肺炎が生じるが, 16 同 じアジア人である韓国などでも頻度は高くなく日本人特 有の副作用である. Gefitinibに関する retrospective study で男性・契煙者・非腺癌で間質性肺炎が多く認め られることより, 16 扁平上皮癌症例ではリスクが高くな る可能性がある. WJTOG0203では腺癌症例のさらなる subset analysis で腺癌かつ喫煙者である症例において逐 次的 Gefitinib の生存期間延長効果が最も顕著に示され ていた. Subset analysisであるが，腺癌であれば喫煙者 であっても Gefitinibで生存期間延長効果が期待できる ことを示す初めてのデータである.この population でど
ちらの EGFR-TKI の効果が優れるかを示すデータは今 のところ存在しない.

喫煙に関しては喫煙により Erlotinib の代謝酵素であ る CYP1A4 が誘導されることが知られており, current smoker では非喫煙者ほど血中濃度が上がらないことが 報告されている. 17 同様の血中濃度を得るには $150 \mathrm{mg} /$ dayでは不足であると考えられ，至適投与量につき検証 中である. Gefitinib では代謝に CYP1A4 が関与せず喫煙 の影響は受けない. 禁煙不可能な症例に Erlotinib を投与 するのには注意が必要である。

日本を含むアジアにおいて非契煙者もしくは軽喫煙者 の腺癌患者を対象に初回治療におけるCarboplatin, Paclitaxel 併用療法と Gefitinib 療法を比較する第 III 相 試験(IPASS)が行われ, Gefitinib は標準治療である Carboplatin, Paclitaxel 併用療法と比較したPFSにおいて primary endpoint であった非劣性だけでなく優越性が 示されたことが報告された. 18 WJTOG0203では非契煙 者の腺癌症例では標準的化学療法群でも増悪時に Gefitinib が多くの症例で処方され, 逐次治療群で median survival time（MST）21.7 か月，標準治療群でMST 23.5 か月と非常に良好な治療成績であった．非喫煙者・腺癌 という population では Gefitinibでも Erlotinibでもよい 治療効果が期待できる.

2004 年に EGFR 遺伝子変異が報告され, 19 以後多く の retrospective および prospective な研究が報告され, 特にExon19 の欠失変異や Exon21 での point mutation （L858R）の 2 つの EGFR 遺伝子変異陽性は最も promising な EGFR-TKI の効果予測因子である. 20 日本で行わ れたこれら 2 種類の遺伝子変異陽性症例における Gefitinib 治療の前向き試験の統合解析結果が報告され, 21 148 例の EGFR 遺伝子変異陽性患者において Gefitinib 投与で $\mathrm{RR}=76.4 \%, \mathrm{PFS}=9.7$ か月, $\mathrm{MST}=24.3$ か月, 1 年生存率 $76.7 \%$ と非常に良好な結果であった。また, スペインから 2312 例をスクリーニングして上記 Exon19，21 における EGFR 遺伝子変異陽性症例におい て Erlotinibを投与した第 II 相試験の結果が報告された が, 22 同様に良好な結果であった（Exon19；RR= $67.5 \%$, time to progression $(\mathrm{TTP})=13 \mathrm{M}, \quad \mathrm{MST}=27$ M, Exon21; RR=53.6\%, TTP $=10 \mathrm{M}, \mathrm{MST}=16 \mathrm{M}$ ).

EGFR-TKI 耐性化症例の約 $1 / 3$ にみられるとされる $\mathrm{T} 790 \mathrm{M}$ の遺伝子変異を有する症例や K-RAS 遺伝子変 異を有する症例では Erlotinibにも Gefitinibにも感受性 はない. Gefitinib 治療で奏効後耐性化してから Erlotinib に感受性を示した症例報告では, 23 耐性となった時点で もともと有していた L858R の変異に加え L747S という 新しい遺伝子変異が生じていた。この secondary mutation が導入されると in vivo でも in vitro でも Gefitinibに 


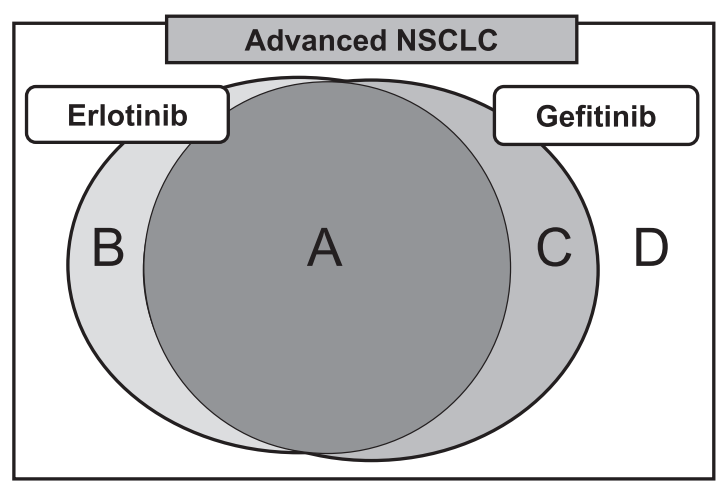

A: patients sensitive to erlotinib \& gefitinib patients harboring sensitizing EGFR mutation (Exon 19 deletion, L858R) never-smokers, adenocarcinoma smokers, adenocarcinoma

$B$ : patients sensitive to only erlotinib patients harboring $L 858 \mathrm{R}+\mathrm{L} 747 \mathrm{~S}$ squamous cell carcinoma

C: patients sensitive to only gefitinib patients harboring L858R+E884K

D: patients resistant to erlotinib \& gefitinib patients harboring K-RAS mutation or resistant EGFR mutation (T790M)

NSCLC; non-small cell lung cancer.

Figure 1. Erlotinib and gefitinib sensitivity populations.

耐性, Erlotinibに感受性であったと報告された。 Erlotinibにて耐性化後 Gefitinib に感受性を示した症例報 告24もありこちらは L858R に加え $\mathrm{E} 884 \mathrm{~K}$ 遺伝子変異が 加わっており，この変異を導入した細胞株では Erlotinib に耐性で Gefitinib に感受性であった。このように minor な遺伝子変異の状況により, 両薬剤への感受性が異なる ことがある.しかし，これらの差が生じるとされる遺伝 子変異の頻度は低く, それぞれの変異の臨床的意義は大 きくはなさそうである.

非小細胞肺癌患者を Gefitinib, Erlotinibで clinical benefit が期待できるか否かで分類し，集合図にした概念 図を Figure 1 に示す。これまでの知見で振り分けてみる と, 両薬剤で最も効果が期待できるのが sensitizing EGFR mutation 陽性症例（Exon19 の 15 base deletion と Exon21 の L858R）である (Figure 1A). IPASSを含 め種々の報告で奏効率, 生存率が良好な非喫煙者の腺癌 症例もここに該当する.WJTOG0203で Gefitinibでの survival benefit が示唆され, BR21 でも survival benefit が示唆される喫煙者の腺癌症例も両薬剤で奏効が期待さ れるが, 腺癌全体において奏効率・生存期間, 治療成功 期間に差があるのかどうか, 腺癌の中で効果の異なる subset が含まれるか否かは現在のところ不明である。両 者の奏効が期待される場合には毒性の軽い Gefitinibを 使うという考え方がある，毒性が強ければ治療成功期間 が短くなるという仮説も成り立つが, Imatinibの倍量投 与が GIST 症例で PFS を伸ばしたように，より効果が強 ければPFSが伸びるとする仮説もあり，生存期間を endpoint とした直接比較試験を行わなければ明確な答 えは出ない. EGFR-TKI 耐性と考えられる K-RAS mutation や耐性の遺伝子変異とされる T790M を有する症例 は両薬剤ともに選択肢とならない（Figure 1D).

これまでの報告からは EGFR 遺伝子変異の status で L858R + L747S ならば Erlotinib が(Figure 1B), L858R + E884K ならば Gefitinib (Figure 1C) が钊められるがこれ らは minor population と考えられる。このような Gefitinib か Erlotinib のいずれか一方のみを明確に勧められ る population は今のところ極めて少ない.これらどちら かのみが勧められる population が多くなっていくこと で使い分けが進むことになるものと考える．扁平上皮癌 の症例で EGFR-TKIの投与を考える場合には Erlotinib が選択されるであろうが日本人におけるその安全性や有 効性についてはこれからさらに検証する必要があり, 今 のところは積極的に勧められるものではない.

\section{Erlotinib・Gefitinib いずれか一方が耐性化もしくは 無効であった場合の治療戦略}

韓国から小規模な第 II 相試験であるが Gefitinibで failure となった症例に Erlotinib 治療を行った前向き試 験の結果が報告されている. ${ }^{25} 21$ 例中 Gefitinibでの最 良効果が SDであった 4 症例では 2 例に partial response (PR)，1 例に90日以上の SD が得られたが，Gefitinib で PR 後の二次無効の 6 症例では 4 例で progressive disease (PD), 2 例で SD, Gefitinib が無効であった 11 症例では 10 例が PD, 1 例で SD の結果であった。 そ の後いくつか Gefitinib 治療後の Erlotinib の報告がなさ れ, Gefitinib で PR P PDであった症例でも Erlotinib の奏効例があることなども示されているが，今までの数 報告をまとめた報告26 では Erlotinib に変更して benefit が得られた 16 症例中の Gefitinib 治療時の最良効果は $\mathrm{SD}$ が 9 例, $\mathrm{PR}$ が 4 例, PD が 3 例であった. 変更が無効 であった 22 例では Gefitinib 治療時の最良効果は SD が 1 例, PR が 9 例, PD が 12 例となっており, やはり Gefitinib 治療で SD であった症例で Erlotinib での再治療 の効果が高そうである. Erlotinib で failure 後の Gefitinib 治療の第 II 相試験も 1 報あり，12 例中 6 例の SD（うち 3 例は 6 か月以上の TTP) が得られている。この報告で は Erlotinibで何らかの臨床効果があった症例でのみ Gefitinib 治療で効果が得られると結論されている. 2008 年の ASCO で EGFR 遺伝子変異のある 18 症例で Gefitinibにfailure 後の Erlotinib の効果をみた報告があっ た. ${ }^{27}$ Gefitinib 治療では 14 例（78\%）にPR が得られた が Gefitinib に resistantとなった後の Erlotinib で PR が 得られたのは 1 例, SD が 3 例のみであった. 再度 EGFR 遺伝子変異が検索できた 7 例中 6 例に T790M の遺伝子 
変異が加わっており, 耐性化に T790M が関与すること により別の EGFR-TKI に変更しても効果を得られない 原因になることが示唆された。 共通の耐性化因子である T790M や MET amplification がある症例では別の EGFR-TKI への変更では臨床効果は得られないものと 考えられる.T790M に対してはirreversible EGFR-TKI など second generation EGFR-TKIの効果が期待されて いる.

Gefitinibに関しては二次無効後の再投与の報告が複 数あり, 28,29 良好な効果が得られた症例では再投与で再 度 benefit が得られる可能性がある.より長い奏効が得 られていた症例や長期間の休薬期間がある症例, 何らか の cytotoxic chemotherapyを再投与前に行うことなど が奏効因子として議論されているが結論は得られていな w.

EGFR-TKIの奏効例においてはEGFR-TKI 無効と なった後であっても EGFR-TKI 中止後に急激な悪化が みられることも報告され, 30 中止せず別の抗癌剤を追加 することも検討されている. 再投与がよいのか他方の EGFR-TKI への変更がよいのか, 他剤の追加がよいのか についても今のところは不明である.

\section{おわりに}

今までの知見を述べてきたが，明確な使い分けは示せ ないのが現状である，両薬剤を用いた前向き試験が必要 であると考えられるが, 現在 WJOG で再発腺癌に対する Erlotinib と Gefitinib の head to head $の$ 第 III 相試験が 行われており，この試験が今後治療に大きな影響をもつ evidence をもたらしてくれることを期待している.

\section{REFERENCES}

1. Thatcher N, Chang A, Parikh P, Rodrigues Pereira J, Ciuleanu T, von Pawel J, et al. Gefitinib plus best supportive care in previously treated patients with refractory advanced non-small-cell lung cancer: results from a randomised, placebo-controlled, multicentre study (Iressa Survival Evaluation in Lung Cancer). Lancet. 2005;366: 1527-1537.

2. Shepherd FA, Rodrigues Pereira J, Ciuleanu T, Tan EH, Hirsh V, Thongprasert S, et al. Erlotinib in previously treated non-small-cell lung cancer. $N$ Engl J Med. 2005;353: 123-132.

3. Pao W, Miller V, Zakowski M, Doherty J, Politi K, Sarkaria I, et al. EGF receptor gene mutations are common in lung cancers from "never smokers" and are associated with sensitivity of tumors to gefitinib and erlotinib. Proc Natl Acad Sci U S A. 2004;101:13306-13311.

4. Kobayashi S, Boggon TJ, Dayaram T, Jänne PA, Kocher O, Meyerson M, et al. EGFR mutation and resistance of non-small-cell lung cancer to gefitinib. $N$ Engl J Med. 2005; 352:786-792.
5. Engelman JA, Zejnullahu K, Mitsudomi T, Song Y, Hyland C, Park JO, et al. MET amplification leads to gefitinib resistance in lung cancer by activating ERBB3 signaling. Science. 2007;316:1039-1043.

6. Karaman MW, Herrgard S, Treiber DK, Gallant P, Atteridge CE, Campbell BT, et al. A quantitative analysis of kinase inhibitor selectivity. Nat Biotechnol. 2008;26: 127-132.

7. Fukuoka M, Yano S, Giaccone G, Tamura T, Nakagawa K, Douillard JY, et al. Multi-institutional randomized phase II trial of gefitinib for previously treated patients with advanced non-small-cell lung cancer (The IDEAL 1 Trial). J Clin Oncol. 2003;21:2237-2246.

8. 西脇 裕, 矢野聖二, 田村友秀, 中川和彦, 工藤新三, 宝 来 威, 他. 非小細胞肺癌患者に対する Gefitinib IDEAL 1 試験の日本人サブセット解析. 癌と化学療法. 2004;31: 567-573.

9. Tamura T, Nishiwaki Y, Watanabe K, Nakagawa K, Matsui K, Takahashi T, et al. Evaluation of efficacy and safety of erlotinib as monotherapy for Japanese patients with advanced non-small cell lung cancer (NSCLC); integrated analysis of two Japanese phase II studies. J Thorac Oncol. 2007;2:S742-S743.

10. Sharma SV, Bell DW, Settleman J, Haber DA. Epidermal growth factor receptor mutations in lung cancer. Nat Rev Cancer. 2007;7:169-181.

11. Varkondi E, Pinter F, Robert K, Schwab R, Breza N, Orfi L, et al. Biochemical assay-based selectivity profiling of clinically relevant kinase inhibitors on mutant forms of EGF receptor. J Recept Signal Transduct Res. 2008;28:295306.

12. McKillop D, Partridge EA, Kemp JV, Spence MP, Kendrew J, Barnett S, et al. Tumor penetration of gefitinib (Iressa), an epidermal growth factor receptor tyrosine kinase inhibitor. Mol Cancer Ther. 2005;4:641-649.

13. Petty WJ, Dragnev KH, Memoli VA, Ma Y, Desai NB, Biddle A, et al. Epidermal growth factor receptor tyrosine kinase inhibition represses cyclin D1 in aerodigestive tract cancers. Clin Cancer Res. 2004;10:7547-7554.

14. Verweij J, Casali PG, Zalcberg J, LeCesne A, Reichardt $\mathrm{P}$, Blay JY, et al. Progression-free survival in gastrointestinal stromal tumours with high-dose imatinib: randomised trial. Lancet. 2004;364:1127-1134.

15. Hida T, Okamoto I, Kashii T, Satouchi M, Ichinose Y, Katakami N, et al. Randomized phase III study of platinum-doublet chemotherapy followed by gefitinib versus continued platinum-doublet chemotherapy in patients (pts) with advanced non-small cell lung cancer (NSCLC): Results of West Japan Thoracic Oncology Group trial (WJTOG). J Clin Oncol. 2008;26(Suppl):S427.

16. Ando M, Okamoto I, Yamamoto N, Takeda K, Tamura $\mathrm{K}$, Seto T, et al. Predictive factors for interstitial lung disease, antitumor response, and survival in non-small-cell lung cancer patients treated with gefitinib. J Clin Oncol. 2006;24:2549-2556.

17. Hamilton M, Wolf JL, Rusk J, Beard SE, Clark GM, Witt $\mathrm{K}$, et al. Effects of smoking on the pharmacokinetics of erlotinib. Clin Cancer Res. 2006;12:2166-2171. 
18. Mok TS, Wu YL, Thongprasert S, Yang CH, Chu DT, Saijo N, et al. Gefitinib or carboplatin-paclitaxel in pulmonary adenocarcinoma. N Engl J Med. 2009;361:947-957.

19. Lynch TJ, Bell DW, Sordella R, Gurubhagavatula S, Okimoto RA, Brannigan BW, et al. Activating mutations in the epidermal growth factor receptor underlying responsiveness of non-small-cell lung cancer to gefitinib. $N$ Engl J Med. 2004;350:2129-2139.

20. Mitsudomi T, Kosaka T, Endoh H, Horio Y, Hida T, Mori $\mathrm{S}$, et al. Mutations of the epidermal growth factor receptor gene predict prolonged survival after gefitinib treatment in patients with non-small-cell lung cancer with postoperative recurrence. J Clin Oncol. 2005;23:2513-2520.

21. Morita S, Hirashima T, Hagiwara K, Hida T, Sunaga N, Sugio K, et al. Gefitinib combined survival analysis of the mutation positives from the prospective phase II trials (I-CAMP). J Clin Oncol. 2008;26(Suppl):S449.

22. Porta C, Cardenal F, Mayo C, Provencio M, Camps C, Isla D, et al. Erlotinib customization based on epidermal growth factor receptor (EGFR) mutations in stage IV non-small-cell lung cancer (NSCLC) patient (p). J Clin Oncol. 2008;26(Suppl):S433.

23. Costa DB, Schumer ST, Tenen DG, Kobayashi S. Differential responses to erlotinib in epidermal growth factor receptor (EGFR)-mutated lung cancers with acquired resistance to gefitinib carrying the L747S or T790M secondary mutations. J Clin Oncol. 2008;26:1182-1186.
24. Choong NW, Dietrich S, Seiwert TY, Tretiakova MS, Nallasura V, Davies GC, et al. Gefitinib response of erlotinib-refractory lung cancer involving meninges--role of EGFR mutation. Nat Clin Pract Oncol. 2006;3:50-57.

25. Cho BC, Im CK, Park MS, Kim SK, Chang J, Park JP, et al. Phase II study of erlotinib in advanced non-small-cell lung cancer after failure of gefitinib. J Clin Oncol. 2007;25: 2528-2533.

26. Cho BC, Kim JH. In Reply (correspondence). J Clin Oncol. 2008;26:1184-1186.

27. Costa DB, Cho BC, Sequist LV, Riely GJ, Halmos B, Kim $\mathrm{J}$, et al. Lack of efficacy of erlotinib in most EGFR mutated non-small cell lung cancers (NSCLCs) with acquired resistance to gefitinib. J Clin Oncol. 2008;26(Suppl): S450.

28. Yokouchi H, Yamazaki K, Kinoshita I, Konishi J, Asahina $\mathrm{H}$, Sukoh N, et al. Clinical benefit of readministration of gefitinib for initial gefitinib-responders with non-small cell lung cancer. BMC Cancer. 2007;7:51.

29. 草間由紀子, 小泉知展, 伊東理子, 神田慎太郎, 山本 洋, 久保患嗣, 他. 非小細胞肺癌患者に対する gefitinib 再投 与例の臨床的検討. 肺癌. 2007;47:689-694.

30. Riely GJ, Kris MG, Zhao B, Akhurst T, Milton DT, Moore E, et al. Prospective assessment of discontinuation and reinitiation of erlotinib or gefitinib in patients with acquired resistance to erlotinib or gefitinib followed by the addition of everolimus. Clin Cancer Res. 2007;13:5150-5155. 